\title{
The implementation of BORDA and PROMETHEE for decision making of Naval base selection
}

\author{
Ahmadi $^{a^{*}}$ and Didit Herdiawan ${ }^{\mathrm{a}}$
}

${ }^{a}$ Indonesian Naval Technology College, STTAL, Surabaya Indonesia

\begin{tabular}{l}
\hline C H R O N I C L E \\
\hline Article history: \\
Received October 28, 2020 \\
Received in revised format: \\
October 29, 2020 \\
Accepted November 172020 \\
Available online \\
November 17, 2020 \\
\hline Keywords: \\
Naval Base \\
Decision Making \\
Borda \\
Promethee
\end{tabular}

\begin{abstract}
A B S T R A C T
The objective of this research is to determine the location for the dock and office of naval bases in Padang city of Indonesia. Following this objective, the Regional Government of Padang Mentawai Islands District provides 3 (three) alternative places namely in Semabuk Bay, Siuban Bay, and Semebai Bay for the location of dock and office of Naval Base. For the selection of Mentawai base, the method uses BORDA and PROMETHEE, since the methods can consider alternative evaluation based on factors that are both qualitative and quantitative. Based on the research of BORDA method calculation on 16 naval base selection criteria, it is found that criterion of Sailing Flow maintains the highest weight value that is equal to $10.9 \%$ and the lowest criterion weighted value belongs to criterion Political Condition for about $2 \%$. For the results of ranking against the alternative using the Promethee method, the study obtains Semebai Bay as the best location to serve for the location of the base of the Mentawai Naval Base.
\end{abstract}

\section{Introduction}

Indonesian navy as the main component of state defense in the sea seeks to always maintain sea security. The Naval Base is the spearhead of the power in carrying out support for the task of combat operations, especially as a supporter of warship operations. The Mentawai Islands Regency is the outermost archipelago of the West Sumatra Province which lies along the westernmost part of Sumatra island which is surrounded by the Indian Ocean. This area has abundant marine potentials such as fish wealth, marine tourism potential, and the front row of islands that are close to the neighboring country (Nugroho et al., 2019). Given the geographical condition and the potential of natural resources, it often triggers illegal fishing practices and cross-border violations committed by foreign ships passing around the Mentawai islands, in addition to this, area is prone to earthquakes. To suppress the rampant illegal fishing practices, supervision of foreign ships, and support the disaster relief operations that may occur in the Mentawai Islands, the Padang naval base plans to form a naval base. Thus, the Navy in cooperation with the local government of the Mentawai Islands District has provided 3 (three) alternative places or location options to be selected as Base (in this case as dock and office location). To select the location of the base, it is necessary to analyze the three alternatives to be selected as the best base location. This is very important because the best base is a base that can ensure the implementation of combat support, logistical support, and administrative support to each navy operation unit in the framework of marine control and can ensure continuous operation of Fleet Weapons System Integrated component operation (Ahmadi, 2019). So far, the method used in determining the location of the naval base is based on the results of the team's decision which is the result of qualitative brainstorming and sometimes in the elements of the subjectivity of the people in the team. Besides, problems that often occur sometimes tops as decision-makers know the criteria that affect the decision, but cannot let where the criteria are very influential and which are lacking (Reza, \& Nugroho, 2020).

* Corresponding author.

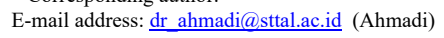

(C) 2021 by the authors; licensee Growing Science, Canada.

doi: $10.5267 /$ j.dsl.2020.11.006 
Decision-making will become complex if each alternative has advantages over different criteria (Saaty, 2001). Suppose the alternative of Semabuk Bay is superior in terms of criteria of the social condition of society and supporting facilities of staple food, Siuban Bay alternative is superior to the criteria of the shipping channel and health and education facilities, while the third alternative of Semebai Bay is superior in criteria of amphibious landing location and coastal morphology conditions. Taking into account the advantages of each alternative will make it difficult for a decision-maker to determine which alternatives will be selected (Sumantri, 2019). In this research, it is proposed the use of a method that can consider alternative evaluation based on qualitative and quantitative criteria, and also attempt to facilitate decision making by analyzing criteria that significantly influence the base determination by using Borda method, so we will get the criterion weight which has significant influence in determining the base selection policy (Salvatore, 2012). According to Brans Roy (1986) PROMETHEE (Preference Ranking Organization Method for Enrichment Evaluation) method can fix Borda method to rank the alternatives based on the assessment of survey data with the weighting obtained from the Borda method (Mareschal et al., 2008), so it is hoped to be able to get the best Mentawai naval base selection. The formulation is based on the description above and the problem that can be formulated as "How to model decision making in location selection of Naval Base of Mentawai by using a combination of Borda and Promethee method to get the best location fulfilling criterion based on standardization Base".

The purpose of this research is to first model the decision-making problem to select the location of the Mentawai naval base based on the standardization of the naval base and analyze the criteria that affect significantly. The second applies a decisionmaking model using a combination of Borda and Promethee methods to get the best of naval base location from three alternate locations: Semabuk bay, Siuban, and Semebai bay. While the benefits of this research are first to make a significant criteria analysis and influential towards the system in the selection of the location of the Mentawai naval base and the second as a reference navy chief in considering the policy in choice of location of Mentawai naval base (Susilo, 2020).

\section{Materials and method}

\subsection{Flowchart research}

This research flowchart uses BORDA and PROMETHEE integration. Research begins with field observation/location and collects data from the literature.

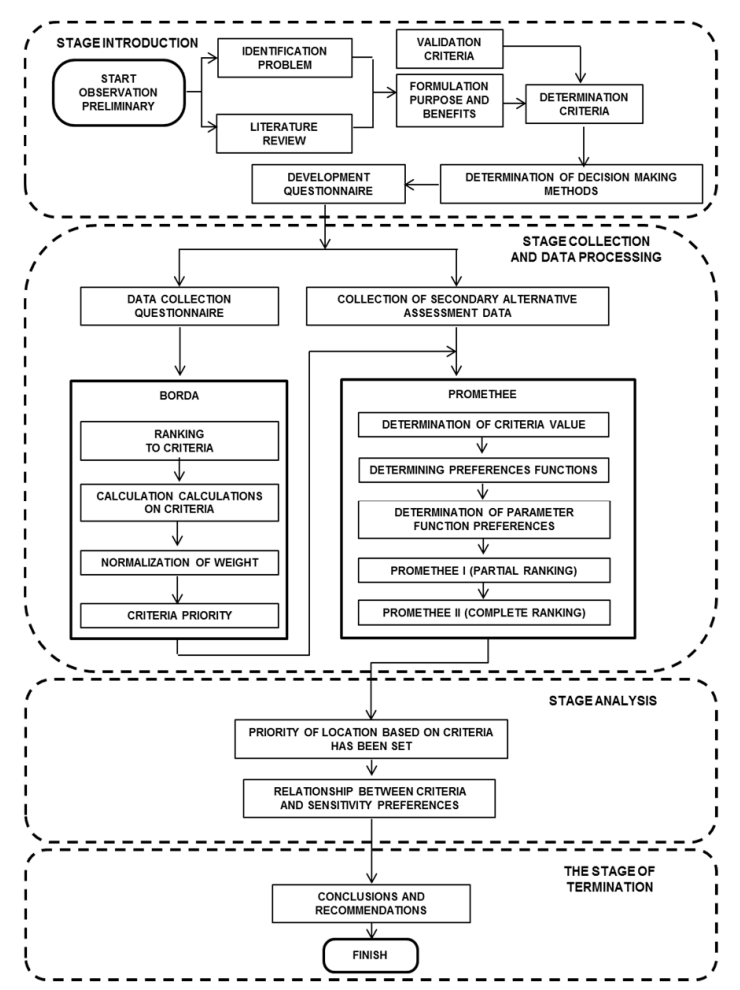

Fig. 1. Flowchart of Research

\subsection{Criteria determination}

Indonesian Naval Base requirements include Port Facility, Maintenance, and Repair Facility, Supplies or Logistics Facility, Personnel Care Facility, and Training Base Facility (Reza \& Nugroho, 2020). The model can be formulated about the criteria that will serve as the determinant criterion for the selection of the location of the Naval base of Mentawai as shown in Fig. 2 . 


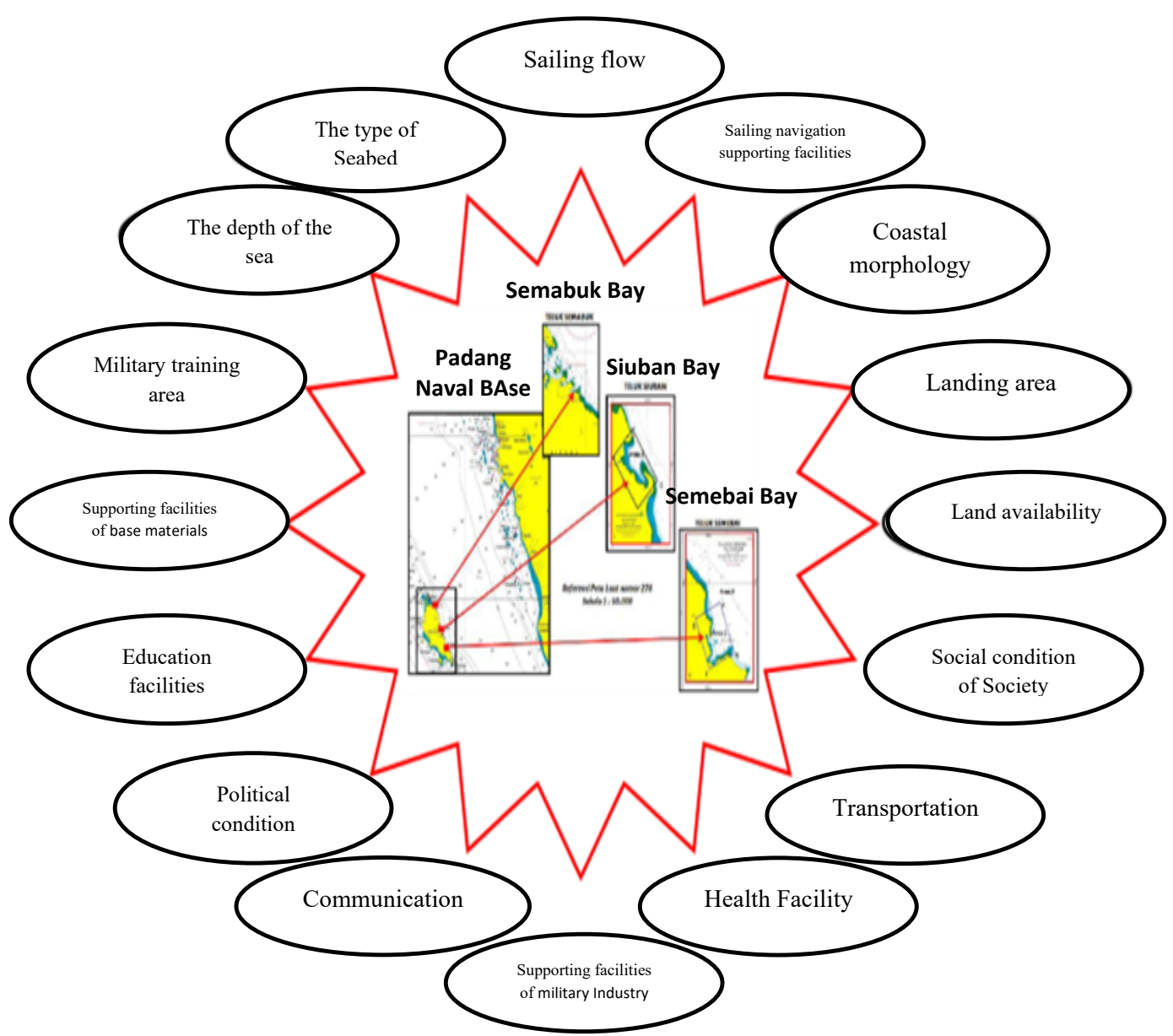

\subsection{Borda method}

Fig. 2. Model Selection Criteria Location of Naval Base Selection

The Borda method was proposed by Jean Charles de Borda in the 18th century. The privilege of this method can overcome the difficulties of other methods where people/things that are not in the first rank will be automatically eliminated (Ahmadi, 2017). The basic idea in the Borda method is to give weight to each of the first ranking criteria, second rank, and so on. The criteria importance assessment (Herdiawan et al., 2020) are described as equation 1 as follows:

$$
R_{j}=\sum_{i=1}^{n} R_{i j}
$$

where:

$R_{j}:$ The sum of rankings is weighted for all criteria $j$

$\mathrm{R}_{\mathrm{ij}}$ : The rank evaluated by $\mathrm{i}$ for criterion $\mathrm{j}$

As for the weight obtained as:

$$
W_{j}=\frac{R_{j}}{\sum_{i=1}^{m} R_{j}}
$$

where $W_{\mathrm{j}}$ is the weight of criterion $j$. :

\subsection{PROMETHEE (Preference Ranking Organization Method For Enrichment Evaluation)}

According to Salvatore (2012) Promethee is a method of determining the order (priority) in the multicriteria analysis (Salvatore Corrente, 2012). The key issues are simplicity, clarity, and stability. The alleged predominance of the criteria used in Promethee is the use of value in outranking relationships (Brans Roy, 1986). All the parameters that are stated have a real influence according to the economic view. The principle used is an alternative priority assignment that has been set based on consideration $(\forall-\mid / f i(,) \rightarrow \Re[$ Realword] $)$, with the basic rules: 
$\max \{\mathrm{f} 1(\mathrm{x}), \mathrm{f} 2(\mathrm{x}), \mathrm{f} 3(\mathrm{x}), \ldots \ldots \mathrm{fj}(\mathrm{x}), \ldots \mathrm{Fk}(\mathrm{x}) / \mathrm{x} \quad\}$

where $K$ is a set of alternatives, and $\mathrm{f}_{\mathrm{i}}(\mathrm{i}=1,2,3, \ldots . ., \mathrm{K})$ is the relative value/size of the criterion for each alternative. In its application, some criteria have been set to explain $\mathrm{K}$ which is an assessment of $\mathfrak{R}$ (real word). Promethee belongs to the family of outranking methods developed by Brans Roy (1986) which includes two phases:

a. Building an outranking relationship from $\mathrm{K}$.

b. The exploitation of this relationship provides an optimization answer to the criteria in the paradigm of multicriteria problems.

In the first phase, the value of outranking relationships is based on the consideration of the dominance of each criterion. The Preference Index is set and the outranking values are graphically presented based on the preferences of the decisionmaker. Preferences structure is built based on criteria (as seen in Eq. (4)):

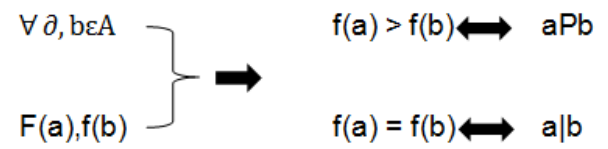

The basic data for evaluation with the Promethee method are presented as follows:

Table 1

Basic Data Analysis of Promethee

\begin{tabular}{ccccccc}
\hline & $\mathrm{f}_{1}()$. & $\mathrm{f}_{2}()$. & $\ldots$ & $\mathrm{f}_{\mathrm{j}}()$. & $\ldots$ & $\mathrm{f}_{\mathrm{k}}()$. \\
\hline $\mathrm{a}_{1}$ & $\mathrm{f}_{1}\left(\mathrm{a}_{1}\right)$ & $\mathrm{f}_{2}\left(\mathrm{a}_{1}\right)$ & $\ldots$ & $\mathrm{f}_{\mathrm{j}}\left(\mathrm{a}_{1}\right)$ & $\ldots$ & $\mathrm{f}_{\mathrm{k}}\left(\mathrm{a}_{1}\right)$ \\
$\mathrm{a}_{2}$ & $\mathrm{f}_{1}\left(\mathrm{a}_{2}\right)$ & $\mathrm{f}_{2}\left(\mathrm{a}_{2}\right)$ & $\ldots$ & $\mathrm{f}_{\mathrm{j}}\left(\mathrm{a}_{2}\right)$ & $\ldots$ & $\ldots$ \\
$\ldots$ & $\ldots$ & $\ldots$ & $\ldots$ & $\ldots$ & $\ldots$ \\
$\mathrm{a}_{\mathrm{i}}$ & $\mathrm{f}_{1}\left(\mathrm{a}_{\mathrm{i}}\right)$ & $\mathrm{f}_{2}\left(\mathrm{a}_{\mathrm{i}}\right)$ & $\ldots$ & $\mathrm{f}_{2}\left(\mathrm{a}_{\mathrm{i}}\right)$ & $\ldots$ & $\ldots$ \\
$\ldots$ & $\ldots$ & $\ldots$ & $\ldots$ & $\ldots$ & $\ldots$ & $\mathrm{f}_{2}\left(\mathrm{a}_{\mathrm{i}}\right)$ \\
$\mathrm{a}_{\mathrm{n}}$ & $\mathrm{f}_{1}\left(\mathrm{a}_{\mathrm{n}}\right)$ & $\mathrm{f}_{2}\left(\mathrm{a}_{\mathrm{n}}\right)$ & $\ldots$ & $\mathrm{f}_{2}\left(\mathrm{a}_{\mathrm{n}}\right)$ & $\ldots$ & $\ldots$ \\
\hline
\end{tabular}

The value of outranking relationships in Promethee can be explained in the form of Bandono (2019) :

\section{a. Criteria Domination}

The $\mathrm{f}$ value is the real value of criterion $\mathrm{f}: \mathrm{K} \rightarrow \mathfrak{R}$ and the purpose of an optimization procedure for each alternative a $\mathscr{E} \mathrm{k}$, $\mathrm{f}(\mathrm{a})$ is an evaluation of these alternatives for a criterion. When two alternatives are compared, a, b, $\mathscr{E}$ k must be determined by a comparison of their preferences (Nugroho et al., 2020a,b). Intensity delivery (P) of alternative preferences to alternative $\mathrm{b}$ is built such that:

1) $\quad \mathrm{P}(\mathrm{a}, \mathrm{b})=0$ means there is no indifferent between $a$ and $b$, or no preferences of a more both from $b$.

2) $\quad \mathrm{P}(\mathrm{a}, \mathrm{b}) \sim 0$ means the weak preference of $a$ is better than $b$.

3) $\mathrm{P}(\mathrm{a}, \mathrm{b}) \sim 1$ means the strong preference of $a$ is better than $b$.

4) $\quad \mathrm{P}(\mathrm{a}, \mathrm{b})=1$ means the absolute preference of $a$ is better than $b$.

From this method, the preference function often results in different function values between the two evaluations, so that:

$$
P(a, b)=P(f(a)-f(b))
$$

For all criteria, an alternative will be considered to have a better criterion value determined by the value of $f$ and from the accumulation of this value determines the preference value of each alternative to be selected.

\section{b. Recommended Function Preferences for Application}

Promethee presented six forms of criteria preference function. This is of course not absolute, but this form is good enough for some cases. To provide a better picture of unequal areas, a function of the difference between the alternate values of $\mathrm{H}$ (d) is used, where this has a direct relationship to the preferences function P:

$$
H(d)=\left\{\begin{array}{l}
P(a, b), d \geq 0 . \\
P(b, a), d \leq 0 .
\end{array}\right.
$$

The 6 (six) general types of preferences in which the decision-maker can choose, and the parameters to be made permanent. The decision-maker can adjust the form of the problem with parameters that make a significant influence on the economic 
aspects. As mentioned above, the process of determining the preference is an important step so that the calculation of preference index can be representative of the problem. Table 2 shows the the level of preference.

Table 2

Determination of Preference Level

\begin{tabular}{|c|c|c|c|c|c|c|}
\hline \multirow{2}{*}{ Consideration } & \multicolumn{6}{|c|}{ Function Level Preferences } \\
\hline & I & II & III & IV & $\mathbf{V}$ & VI \\
\hline Accuracy & Rude & Rude & Accurate & Rude & Accurate & Accurate \\
\hline The trend is no different $|\mathrm{d}|<\mathrm{q}$ & No & Yes & No & Yes & Yes & No \\
\hline Absolute solid tendency $|\mathrm{d}|<\mathrm{q}$ & No & No & No & Yes & Yes & No \\
\hline Normal distribution & Maybe & Maybe & Maybe & Maybe & Maybe & Yes \\
\hline
\end{tabular}

c. Index of Multicriteria Preferences (Ehrgott, 2010)

The purpose of the decision-maker is to set the preferences function $P$, and $\pi_{i}$ for all criteria $\mathrm{f}_{\mathrm{i}}(\mathrm{i}=1, \ldots, \mathrm{k})$ of the compound criterion optimization problem (Nugroho, 2019). The weight $\pi_{\mathrm{i}}$ is a relative measure of the importance of the criterion $\mathrm{f}_{\mathrm{i}}$; if all criteria have equal importance in decision making then all weight values are equal. The multi-criterion preferences index is determined by the weighted average of the $P_{i}$, which is preference function as follows,

$$
\wp(\mathrm{a}, \mathrm{b})=\sum_{\mathrm{i}=1}^{\mathrm{n}} \pi \mathrm{Pi}(\mathrm{a}, \mathrm{b}): \forall \mathrm{a}, \mathrm{b} \varepsilon \mathrm{A}
$$

$\wp(\mathrm{a}, \mathrm{b})$ is the intensity of the decision maker's preference which states that alternative $a$ is better than alternative $b$ with simultaneous consideration of all criteria. It can be presented with a value of 0 to 1 , subject to the following conditions:

1) $\wp(\mathrm{a}, \mathrm{b})=0$, showing a weak preference for alternative an over alternate $b$ based on all criteria.

2) $\wp(\mathrm{a}, \mathrm{b})=1$, shows a strong preference for alternative an over alternate $b$ based on all criteria.

The preference index is determined based on the value of outranking relationships on several criteria from each alternative. This relationship can be presented as a graph of the value of outranking, the nodes are alternatives based on the assessment of certain criteria. Among the two nodes (alternatives), $a$ and $b$, are curved lines having values $\wp(\mathrm{a}, \mathrm{b})$ (no relation between $\wp(\mathrm{a}, \mathrm{b})$ and $\wp(\mathrm{b}, \mathrm{a})$ and the relationship can be seen in Fig. 3.

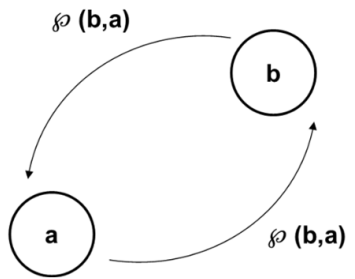

\section{Results and discussion}

Fig. 3. Relationships between nodes

\subsection{Data processing}

The steps of data processing are done as follows:

Conduct weighted processing on criteria based on expert questionnaire results

Processe the result of weighting Borda method as shown in Tables 3 and 4.

Table 3

Processing Borda Methods

\begin{tabular}{|c|c|c|c|c|c|c|c|c|c|c|c|c|c|c|c|c|c|}
\hline \multicolumn{2}{|c|}{ Criteria } & C1 & $\mathrm{C2}$ & C3 & $\mathrm{C4}$ & C5 & C6 & C7 & C8 & C9 & C10 & C11 & C12 & C13 & C14 & C15 & C16 \\
\hline \multirow[b]{2}{*}{ NPS } & 1 & 15 & 11 & 13 & 12 & 14 & 1 & 2 & 5 & 6 & 7 & 3 & 4 & 9 & 10 & 0 & 8 \\
\hline & 2 & 15 & 11 & 12 & 13 & 14 & 6 & 7 & 1 & 10 & 0 & 9 & 8 & 4 & 3 & 5 & 2 \\
\hline \multirow{3}{*}{ NOS } & 1 & 11 & 8 & 3 & 2 & 15 & 1 & 4 & 6 & 13 & 5 & 7 & 10 & 9 & 0 & 14 & 12 \\
\hline & 2 & 13 & 12 & 5 & 10 & 11 & 9 & 8 & 7 & 6 & 4 & 3 & 2 & 1 & 0 & 15 & 14 \\
\hline & 1 & 9 & 8 & 7 & 6 & 5 & 4 & 3 & 2 & 10 & 11 & 12 & 13 & 1 & 0 & 15 & 14 \\
\hline \multirow[t]{2}{*}{ NBF } & 2 & 15 & 12 & 11 & 10 & 9 & 4 & 2 & 14 & 1 & 13 & 7 & 6 & 5 & 0 & 8 & 3 \\
\hline & 1 & 14 & 12 & 13 & 10 & 15 & 9 & 8 & 6 & 7 & 5 & 3 & 1 & 3 & 0 & 11 & 5 \\
\hline HIDROS & 2 & 13 & 7 & 12 & 15 & 14 & 1 & 2 & 3 & 11 & 0 & 4 & 5 & 10 & 6 & 9 & 8 \\
\hline \multicolumn{2}{|c|}{ TOTAL } & 105 & 81 & 76 & 78 & 97 & 35 & 36 & 44 & 64 & 45 & 48 & 49 & 42 & 19 & 77 & 66 \\
\hline \multicolumn{2}{|c|}{$\begin{array}{l}\text { WEIGHTING } \\
\text { CRITERIA }\end{array}$} & 0.109 & 0.084 & 0.079 & 0.081 & 0.101 & 0.036 & 0.037 & 0.046 & 0.067 & 0.047 & 0.050 & 0.051 & 0.044 & 0.020 & 0.080 & 0.069 \\
\hline \multirow{2}{*}{\multicolumn{2}{|c|}{$\begin{array}{c}\text { THE ORDER } \\
\text { OF } \\
\text { CRITERIA }\end{array}$}} & 0.109 & 0.084 & 0.079 & 0.081 & 0.101 & 0.036 & 0.037 & 0.046 & 0.067 & 0.047 & 0.050 & 0.051 & 0.044 & 0.020 & 0.080 & 0.069 \\
\hline & & 1 & 3 & 6 & 4 & 2 & 15 & 14 & 12 & 8 & 11 & 10 & 9 & 13 & 16 & 5 & 7 \\
\hline
\end{tabular}


Table 4

Weighted Borda Method

\begin{tabular}{|c|c|c|c|c|c|c|c|}
\hline $\begin{array}{c}\text { No } \\
\text { Weight }\end{array}$ & Criteria & Code & Weight & $\begin{array}{c}\text { No } \\
\text { Weight }\end{array}$ & Criteria & Code & Weight \\
\hline 1 & Sailing Flow & K1 & 0.109 & 9 & Health Facility & K12 & 0.051 \\
\hline 2 & The Deep of the Sea & K5 & 0.101 & 10 & Education Facilities & K11 & 0.050 \\
\hline 3 & $\begin{array}{c}\text { Sailing Navigation } \\
\text { Supporting Facilities (SNSF) }\end{array}$ & $\mathrm{K} 2$ & 0.084 & 11 & $\begin{array}{c}\text { Supporting Facilities of Maritime } \\
\text { Industry }\end{array}$ & K10 & 0.047 \\
\hline 4 & Coastal Morphology & $\mathrm{K} 4$ & 0.081 & 12 & Land Availability & K8 & 0.046 \\
\hline 5 & Transportation Facilities & K15 & 0.080 & 13 & Social Condition of Society & K13 & 0.044 \\
\hline 6 & Seabed Type & $\mathrm{K} 3$ & 0.079 & 14 & Military Training Area & K7 & 0.037 \\
\hline 7 & Means of Communication & K16 & 0.069 & 15 & Landing Area & K6 & 0.036 \\
\hline 8 & $\begin{array}{c}\text { Supporting Facilities of Base } \\
\text { Materials }\end{array}$ & K9 & 0.067 & 16 & Political Condition & K14 & 0.020 \\
\hline
\end{tabular}

b. After obtaining the weight of each criterion, the next step is to process the results of alternative assessment using the Promethee method using Microsoft Excels software and to facilitate the analysis of Promethee using Visual Promethee Version 1.1.0.0 which is a tool in solving Promethee method. The working order is as follows:

1) Determination of Criteria Preference Type. The determination of this type of preference is determined through brainstorming with decision-makers and based on data accuracy. Guidelines for data selection based on data accuracy are presented in Table 5.

Table 5

Type selection

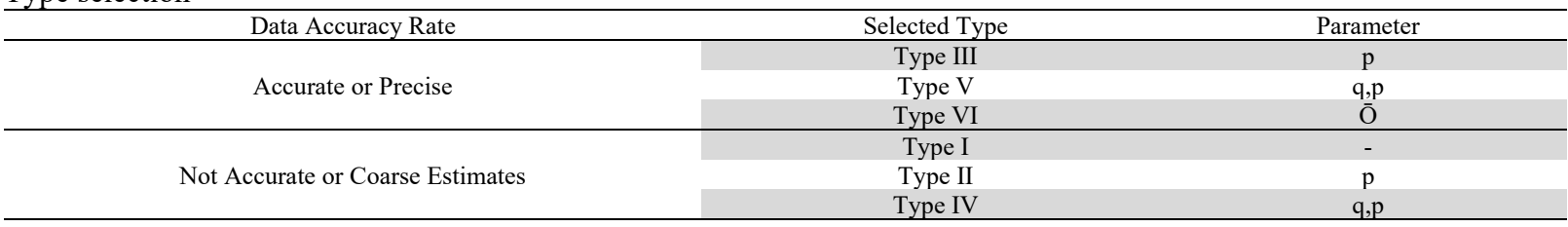

2) Then the research on the tendency is not different if the appreciation of the value is below the parameter value $p$, if it does not tend to the parameter value of $p$ then the possible types are type II, type III, type IV and type V. Next is the assessment for different tendencies absolute after exceeding the parameter value q. If it has an absolute distinct tendency after it exceeds the parameter q, then the type chosen is type IV and type $\mathrm{V}$. If the values $|\mathrm{d}|$ form a normal distribution, then the type of preferred function selected is type IV. A complete selection of preference types is presented in Table 6.

Table 6

Type of Preference Criteria

\begin{tabular}{ccccc}
\hline No & Criteria & $\begin{array}{c}\text { Criteria } \\
\text { Type }\end{array}$ & No & Criteria \\
\hline 1 & Sailing Flow & Type III & 9 & Supporting Facilities of Base Materials \\
2 & Sailing Navigation Supporting Facilities (SNSF) & Type III & 10 & Supporting Facilities of Maritime Industry \\
3 & Seabed Type & Type V & 11 & Type II \\
4 & Coastal Morphology & Type V & 12 & Type III \\
5 & The Depth of the Sea & Type III & 13 & Socilities \\
6 & Landing Area & Type I & 14 & Type III \\
7 & Military Training Area & Type I & 15 & Political Condition \\
8 & Land Availability & Type III & 16 & Transportation Facilities \\
\hline
\end{tabular}

3) Threshold Determination. The threshold value of each criterion is required as a basis to provide an assessment of outranking relationships between alternatives on a given criterion whether an alternative is preferred, not different, or preferably to a certain degree (Suharjo et al., 2019). Thus the threshold value must be given to each criterion, where the person who is considered the most important role here is the decision-maker or expert. The procedure for determining the Threshold value as follows:

a) Calculate the value of the absolute difference between alternative criteria

b) Calculate the range threshold for each criterion, calculating the absolute difference for each criterion by calculating the difference between the maximum and minimum absolute values (Susilo, 2020).

c) Divide the range obtained from step (b) into three classes of the same class width to obtain indifference threshold values or q, preference threshold (p), and veto threshold (v) with rule $\mathrm{q}<\mathrm{p}<\mathrm{v}$. The result of calculating the threshold value as Table 7. 
Table 7

The threshold value of the criteria

\begin{tabular}{|c|c|c|c|c|c|}
\hline \multirow{2}{*}{ No } & \multirow{2}{*}{ Criteria } & \multirow{2}{*}{ Rule } & \multicolumn{3}{|c|}{ Parameter } \\
\hline & & & $\mathbf{q}$ & $\mathbf{p}$ & $\mathbf{s}$ \\
\hline 1 & Sailing Flow & Max & 116.667 & 233.333 & 177.858 \\
\hline 2 & Sailing Navigation Supporting Facilities (SNSF) & Max & 1.333 & 2.667 & 2.000 \\
\hline 3 & Seabed Type & $\operatorname{Max}$ & 0.333 & 0.667 & 0.577 \\
\hline 4 & Coastal Morphology & Max & 0.667 & 1.333 & 1.000 \\
\hline 5 & The Depth of the Sea & Max & 3.333 & 6.667 & 5.774 \\
\hline 6 & Landing Area & $\operatorname{Max}$ & 0.333 & 0.667 & 0.577 \\
\hline 7 & Military Training Area & Max & 0.000 & 0.000 & 0.000 \\
\hline 8 & Land Availability & $\operatorname{Max}$ & 5.000 & 10.000 & 7.638 \\
\hline 9 & Supporting Facilities of Base Materials & $\operatorname{Max}$ & 0.000 & 0.000 & 0.000 \\
\hline 10 & Supporting Facilities of Maritime Industry & Max & 0.667 & 1.333 & 1.000 \\
\hline 11 & Education Facilities & $\operatorname{Max}$ & 0.333 & 0.667 & 0.577 \\
\hline 12 & Health Facility & $\operatorname{Max}$ & 0.333 & 0.667 & 0.577 \\
\hline 13 & Social Condition of Society & Max & 0.000 & 0.000 & 0.000 \\
\hline 14 & Political Condition & Max & 0.000 & 0.000 & 0.000 \\
\hline 15 & Transportation Facilities & $\operatorname{Max}$ & 0.000 & 0.000 & 0.000 \\
\hline 16 & Means of Communication & $\operatorname{Max}$ & 0.000 & 0.000 & 0.000 \\
\hline
\end{tabular}

3) The next step is the calculation of the preference value because there are 3 alternatives then done 3 combinations of preferences.

4) And the final result of the calculation is the calculation of the Preference Index from the combination of the three alternatives. The preference index of $\wp(\mathrm{a}, \mathrm{b})$ is calculated on each pair on the criterion by formula (Herdiawan et al., 2020), then the value of the preference index between alternatives as shown in Table 8 follows.

Table 8

Value of Preference Index

\begin{tabular}{cccc}
\hline IP(a,b) & A1 & A2 & A3 \\
\hline $\mathbf{A 1}$ & 0.0000 & 0.0486 & 0.0000 \\
$\mathbf{A 2}$ & 0.3708 & 0.0000 & 0.2407 \\
$\mathbf{A 3}$ & 0.4720 & 0.1979 & 0.0000 \\
\hline
\end{tabular}

1) Calculation of Preference Direction. By looking at the final results processing then we can learn about the direction of preference. The direction of preference is divided into two directions: Leaving Flow (LF) and Entering Flow (EF). LF is the size of the character outranking a, while EF is the size of a character in outranking. The positive outranking flow $(\mathrm{F}+(\mathrm{a}))$ declares to dominate the other (the power of a). The negative outranking flow $\left(\Phi^{\wedge}+(\mathrm{a})\right)$ states how each alternative is dominated by the other (the weakness of a). The ranking of Promethee I is based on each of the values of LF and EF. The bigger the LF value and the smaller the EF the better the alternative. The parietal ranking of Promethee $\mathrm{I}$ is presented in Fig. 4 below

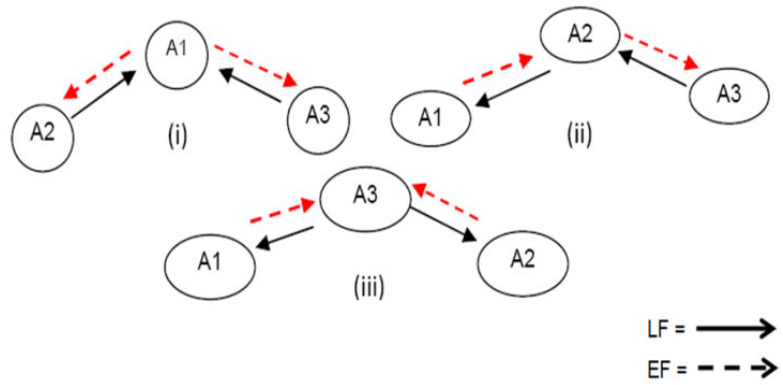

Fig. 4. Node relationship - alternative Promethee I

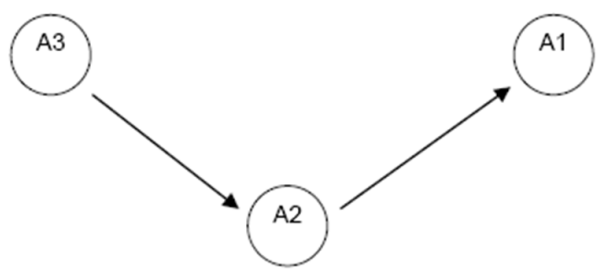

Fig. 5. Node relationship - alternative Promethee II

So the best alternative sequence following the ranking is as follows:
a) Ranking 1 Semebai.
b) Ranking 2 Siuban.
c) Ranking 3 Semabuk.

While Promethee II is based on its Net Flow (NF), the bigger the NF the higher the ranking. The ranking is shown in Fig. 5. Based on Net Flow the best alternative sequence by the following rankings:
a) Ranking 1 Semebai.
b) Ranking 2 Siuban.
c) Ranking 3 Semabuk. 


\subsection{Analysis of Borda Results}

Based on the result of the research, it is found that the criteria of the Sailing Channel (K1) with the weight of $10.9 \%$ is a criterion that significantly affects the determination of base site selection and the second criterion that is the depth of the sea (K5) with the weight of $10.1 \%$. For the other criteria weighs less than $9 \%$, while the criterion that has the lowest weight is the criterion of Political Condition (K14) of $2 \%$.

\subsection{Analysis of Promethee Results}

Promethee is a method that complements or enriches the decision-making process of the preferences function (Herdiawan \& Ahmadi, 2019). In the process of Promethee work is very dependent on the choice of the type of preference conducted on each criterion, because in determining the type of preference is crucial to the result of ranking (Suharjo, 2019). The result of the combination of these two methods resulted in Semebai Bay being ranked first in the selection of base sites.

\subsection{Sensitivity Analysis}

Sensitivity analysis is carried out to determine the extent of the decision changes that occur when the changes are made to the weight of the existing criteria (Setiadji, 2019). Based on data processing by the Promethee II method, the result of the weight sensitivity interval of each criterion is a certain value interval. For the breakdown of sensitivity, values are presented in Table 9.

Table 9

Interval Sensitivity Value

\begin{tabular}{|c|c|c|c|}
\hline No & Criteria & Weight & \% Interval \\
\hline 1 & $\begin{array}{l}\text { Sailing Flow } \\
\end{array}$ & 0.109 & $(0.00 \%, 16.69 \%)$ \\
\hline 2 & Sailing Navigation Supporting Facilities (SNSF) & 0.084 & $(0.00 \%, 14.31 \%)$ \\
\hline 3 & Seabed Type & 0.079 & $(0.00 \%, 100 \%)$ \\
\hline 4 & Coastal Morphology & 0.081 & $(3.64 \%, 100 \%)$ \\
\hline 5 & The Depht of the Sea & 0.101 & $(0.00 \%, 100 \%)$ \\
\hline 6 & Landing Area & 0.036 & $(0.00 \%, 100 \%)$ \\
\hline 7 & Military Training Area & 0.037 & $(0.00 \%, 100 \%)$ \\
\hline 8 & Land Availability & 0.046 & $(1.18 \%, 39.08 \%)$ \\
\hline 9 & Supporting Facilities of Base Materials & 0.067 & $(0.00 \%, 100 \%)$ \\
\hline 10 & Supporting Facilities of Maritime Industry & 0.047 & $(0.09 \%, 100 \%)$ \\
\hline 11 & Education Facilities & 0.050 & $(0.00 \%, 13.01 \%)$ \\
\hline 12 & Health Facility & 0.051 & $(0.00 \%, 13.10 \%)$ \\
\hline 13 & Social Condition of Society & 0.044 & $(0.00 \%, 100 \%)$ \\
\hline 14 & Political Condition & 0.020 & $(0.00 \%, 100 \%)$ \\
\hline 15 & Trasportation Facilities & 0.80 & $(0.00 \%, 100 \%)$ \\
\hline 16 & Means of Communication & 0.69 & $(0.00 \%, 100 \%)$ \\
\hline
\end{tabular}

Based on the sensitivity analysis conducted by Promethee method, the results obtained are sensitive to changes in weight at certain intervals such as changes in the weight of the criteria of Sailing Channel (K1), SNSF (K2), Coastal Morphology (K4), Land Availability (K8), Supporting Facilities Maritime Industry (K10), Health Facilities (K11) and Education Facilities (K12). On these 7 criteria, it can be explained that at this stable level the alternative rankings will not change, but when outside the stable level interval there will be a change of rank on the alternative. As for the other criteria with an increase in weight value up to close to $100 \%$, the predominance of this criterion will certainly not affect the outcome of the sequence of alternatives.

Sensitivity analysis is also done to alternative judgment value, this is done to know how big of change of rank which happened if in the future will experience the change of appraising to the alternative. The assessment of the criteria on each alternative is done on the criteria of SNSF, Land Availability, Support Facilities of the Maritime Industry. And judgment assessment is given to alternatives that have the lowest or lowest value, to be able to know the ranking change of the existing alternatives. The result of the sensitivity analysis of the alternative does not change the ranking.

\section{Conclusion}

Decision-making within an organization is the result of a continuous process of communication and participation of all members of the organization. The model of decision making by combining Borda and Promethee methods is a way of developing logical relationships that underlie the problem of decision making into a mathematical model reflecting the relationships that occur between the criteria involved. Based on the result of the research, it is found that the criteria of the Sailing Channel (K1) with the weight of $10.9 \%$ is a criterion that significantly affects the determination of base site selection, and the second criterion is the Depth of Sea (K5) with the weight of $10.1 \%$. For the other criteria weighs less than $9 \%$, while the criterion that has the lowest weight is the criterion of Political Condition (K14) of $2 \%$. Based on the result of research with Borda and Promethee combination method, the best base location of the Mentawai naval base, in order of priority as follows: 
Sequence 1: Semebai Bay

Sequence 2: Siuban Bay

Sequence 3: Semabuk Bay

Thus we conclude that Semebai Bay is the best location to serve as the location of the Mentawai naval base. In general, the results of sensitivity analysis on the criteria and alternative weightings do not change with the selected alternative ranking result, so it can be said that the model is robust.

\section{Acknowledgement}

The authors greatly acknowledge the support from the Indonesian Navy, and also thanks to Indonesian Naval Technology College STTAL Surabaya Indonesia for providing the necessary resources to carry out this research work. The authors are also grateful to the anonymous reviewers and editorial board for their many insightful comments, which have significantly improved this article.

\section{References}

Ahmadi, \& Herdiawan, D. (2019). The application of CBA and SUG model for improving the quality of Indonesian navy human resources. International Journal of Recent Technology and Engineering, 8(3), 393-399. https://doi.org/10.35940/ijrte.C4190.098319

Ahmadi, Sumantri, S. H., Suharyo, O. S., \& Kukuh Susilo, A. (2017). Selection anti-submarine sensor of the helicopter using the Electre III method. International Journal of Applied Engineering Research, 12(9), 1974-1981.

Bandono, A. D. I., Suharyo, O. S., \& Riono. (2019). Applied fuzzy and NASA tlx method to measure of the mental workload. Journal of Theoretical and Applied Information Technology, 97(2), 476-489.

Brans Roy, P. V. (1986). How to Select and How to Rank Projects: The PROMETHEE Method. European Journal of Operational Research, 228-238.

Herdiawan, D., \& Ahmadi. (2019). Development strategy of national food sovereignty to encounter radicalism threat. International Journal of Innovative Technology and Exploring Engineering, 8(11), 544-553. https://doi.org/10.35940/ijitee.K1570.0881119

Herdiawan, D., Ahmadi, \& Gunawan, K. (2020). The assessment of human resources performance analysis for occupational safety. International Journal of Advanced Science and Technology, 29(5), 5113-5127.

Mareschal, B., De Smet, Y., \& Nemery, P. (2008, December). Rank reversal in the PROMETHEE II method: some new results. In 2008 IEEE International Conference on Industrial Engineering and Engineering Management (pp. 959-963). IEEE.

Nugroho, S. H., Madhakomala, R., \& Gunawan, K. (2019). The system dynamic model for policy evaluation of navy personnel on the state-duty aspect. International Journal of Scientific and Technology Research, 8(12), 228-236.

Nugroho, S. H., Madhakomala, R., \& Gunawan, K. (2019). Analysis and scenario of navy performance allowance policy using system dynamic model. International Journal of Scientific and Technology Research, 8(12), 1140-1147.

Nugroho, S. H., Sukandari, B., Suharyo, O. S., \& Bandono, A. (2020a). The application of Nasa-Tlx methods to the analysis of $\mathrm{Mtf}$ navy personnel allocation. International Journal of Scientific and Technology Research, 9(3), 6172-6179.

Nugroho, S. H., Sukandari, B., Bandono, A., \& Sri Suharyo, O. (2020b). The applications of model bayesian networks for analysis and preventive actions on maritime security operations. International Journal of Scientific and Technology Research, 9(3), 3000-3006.

Reza, H. K., \& Nugroho, S. H. (2020). The assessment of work performance, education, and self motivation on organizational citizenship behavior. International Journal of Advanced Science and Technology, 29(3), 8019-8030.

Saaty. (2001). Decision Making With Dependence and Feedback The Analytic Network Process. Pittsburgh, USA: RWS Publication.

Salvatore Corrente, S. G. (2012). Multiple Criteria Hierarchy Process With ELECTRE and PROMETHEE. Journal of Economics and Business, 60.

Setiadji, A., Marsetio, \& Ahmadi. (2019). The assessment of strategic planning and strategic change management to improve organizational performance. International Journal of Advanced Science and Technology, 29(5), 682-698.

Suharjo, B., Suharyo, O. S., \& Bandono, A. (2019). Failure mode effect and criticality analysis (FMECA) for determination time interval replacement of critical components in warships radar. Journal of Theoretical and Applied Information Technology, 97(10), 2861-2870. https://doi.org/10.5281/zenodo.3256535

Suharjo, B. (2019). Using System Dynamics to Analyze the Leadership Style on Motivation and Soldier's Performance. In E3S Web of Conferences (Vol. 125). EDP Sciences. https://doi.org/10.1051/e3sconf/201912522002

Sumantri, S. H., Bastari, A., \& Sri Suharyo, O. (2019). The assessment of naval base sustainability using a dynamic system thinking approach. International Journal of Scientific and Technology Research, 8(11), 388-394.

Susilo, A. K., Putra, I. N., Ahmadi, \& Suharyo, O. S. (2020). Analysis of national maritime security strategy as an effect of regional development using SWOT, fuzzy multi-criteria decision making (FMCDM), and borda. International Journal of Operations and Quantitative Management, 25(3), 153-174. 
(C) 2021 by the authors; licensee Growing Science, Canada. This is an open access article distributed under the terms and conditions of the Creative Commons Attribution (CC-BY) license (http://creativecommons.org/licenses/by/4.0/). 